\title{
ERRATUM
}

\section{Multifaceted role of $\beta$-arrestins in inflammation and disease}

D Sharma and N Parameswaran

Genes and Immunity (2015) 16, 576; doi:10.1038/gene.2015.47

Correction to: Genes and Immunity (2015) 16, 499-513; doi:10.1038/gene.2015.37; published online 17 September 2015

Since the online publication of this article, the authors have noticed that Table 3 was published incorrectly. The corrected Table 3 is shown here.
The typesetters would like to apologise for this error.

This error has now been rectified, and the corrected article appears in this issue. The html and online pdf versions have also been rectified, and now carry the corrected paper.

Table 3. Role of $\beta$-arrestins in inflammatory diseases

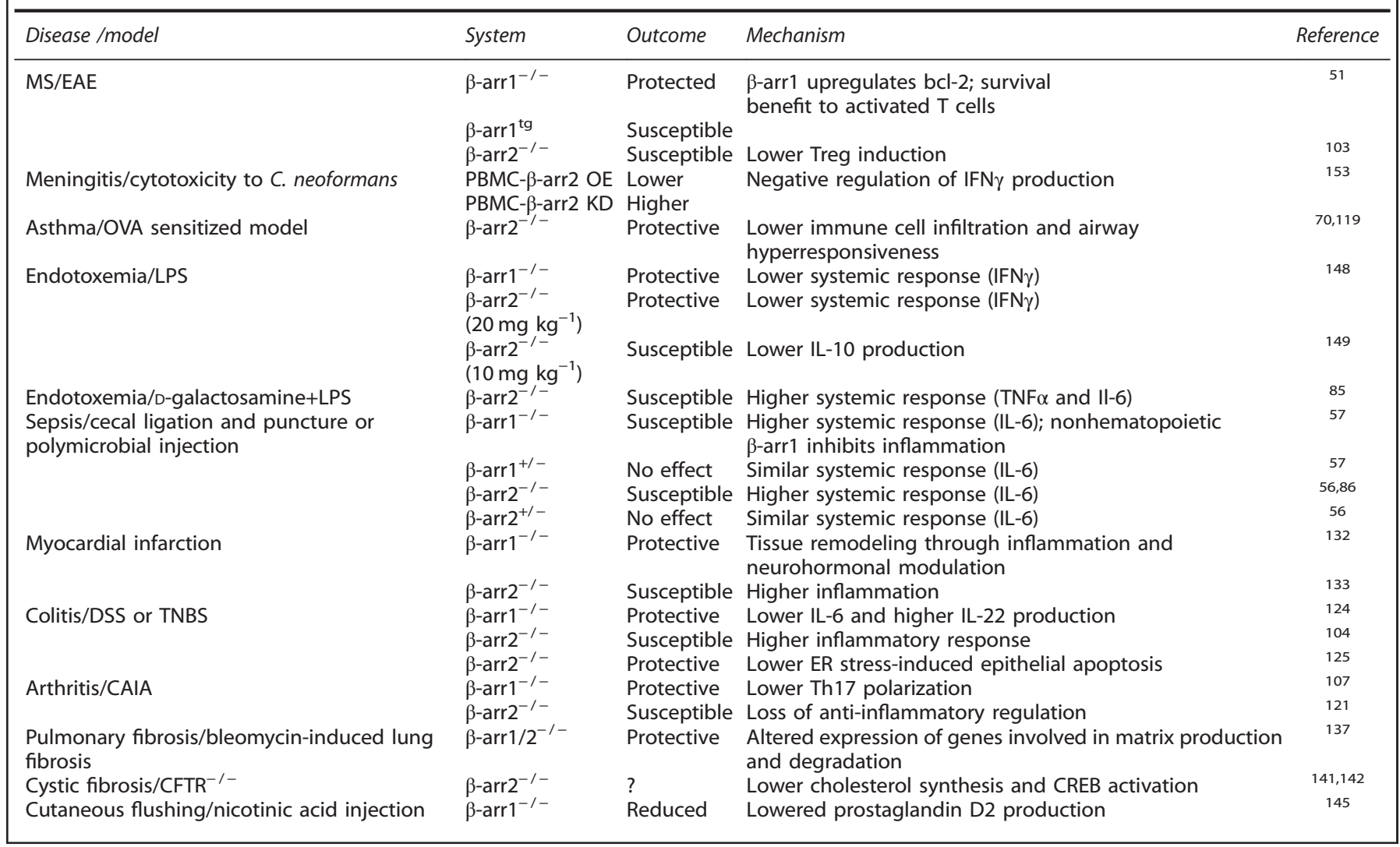

